\title{
THE HEALTH OF TALENT MANAGEMENT PRACTICE'S FACTOR ANALYSIS OF PT XYZ, WEST JAVA
}

\author{
Alya Sania Supriyadi ${ }^{1}$, Syarifuddin ${ }^{2}$ \\ ${ }^{1,2}$ Business Administration, Faculty of Communication and Business, Telkom University \\ Jalan Telekomunikasi, Terusan Buahbatu, Bandung 40257, Indonesia \\ alyasania73@gmail.com
}

\begin{abstract}
Abstrak
Tujuan penelitian ini adalah untuk menganalisis Faktor Kesehatan Praktik Manajemen Talenta PT XYZ. Sebagai perusahaan telekomunikasi dengan kredibilitas yang baik, PT XYZ harus terus berusaha meningkatkan employee engagement dengan mengelola manajemen talenta mereka, berdasarkan data employee engagement PT XYZ terus mengalami penurunan setiap tahun sebesar $1-3 \%$, rendahnya employee engagement dapat membuat $18 \%$ lebih banyak dalam hal turnover. Dengan demikian, makalah ini menguraikan empat faktor utama yang dapat mempengaruhi kesehatan manajemen talenta (deploymentdiagnosis-development-demarcation). Metode yang digunakan dalam penelitian ini adalah metode deskriptif dengan metode pengambilan probability sampling dengan teknik random sampling sederhana. Data diproses melalui first order dan second-order konfirmatori faktor analisis, menggunakan perangkat lunak AMOS versi 24 (n:130). Hasil penelitian ini menunjukkan bahwa Berdasarkan analisis deskriptif diketahui bahwa Deployment memiliki nilai rata-rata $84,3 \%$ yang termasuk dalam kategori sangat tinggi, Diagnosis memiliki skor rata-rata $85 \%$ yang termasuk dalam kategori sangat tinggi, Development memiliki skor ratarata $83,042 \%$ yang termasuk dalam kategori tinggi, sedangkan Demarkasi memiliki nilai rata-rata $82,71 \%$ yang termasuk dalam kategori tinggi.
\end{abstract}

Kata Kunci: Demarkasi, Deployment, Development, Diagnosis, Manajemen Talenta

\begin{abstract}
The aim of this study is to analyze the Health Factor of Talent Management Practice of PT $X Y Z$. As a telecommunication company with good credibility, PT XYZ should keep trying to improve the employee's engagement by manage their talent management according to the data the employee engagement has decreasing every year in the amount of $1-3 \%$, the result of a lack of employee engagement can make $18 \%$ more in high turnover. Accordingly, this paper outlines four main factors that may affect the health of talent management (deployment-diagnosis-development-demarcation). The method used in this research is a descriptive method with probability sampling methods with simple random sampling techniques. Data is processed through the first order and second-order confirmatory factor analysis, using software AMOS version 24 ( $n: 130)$. Results of this study showed that Based on the descriptive analysis it is known that Deployment has an average value of $84.3 \%$ which include in the very high category, Diagnosis has an average score of $85 \%$ which include in the very high category, Development has an average score of $83.042 \%$ which include in the high category, while Demarcation has an average value $82.71 \%$ which include in the high category.

Keywords: Demarcation, Deployment, Development, Diagnosis, Talent Management
\end{abstract}

\section{Introduction}

Over the last few years, the telecommunication industry facing the same problem as many other industries. They have been facing rapid changes resulting not only from globalization but also from the technological development. To have a competitive advantage, organizations need to focus on internal resources and manage them effectively and efficiently, one way to achieving it organization needs to be more concerned with their internal organizational resources, especially human resources. It's very important to place the right people at the right time and place to achieve long-term strategic goals and avoid high turnover.

High turnover can cause many losses for the organization such as the loss of time, energy and assets that spent by the company to develop its talents. Employees usually stay in 
a company if they feel comfortable and happy to work in the company, as a result employees who already feel comfortable and happy with the company become more engaged and commitment level increase. The company will conduct Employee Engagement Survey every year to get information about the level of employee engagement in the organization which later can be used as an evaluation of the strategy for improving human capital management, but based on the data of PT XYZ Regional West Java, their employee engagement has decreasing every year in amount of $1-3 \%$ and if the issue of lack employee engagement continued there are some problem that will occurred such as $23 \%$ less in profitability, $18 \%$ less in productivity, and $18 \%$ more in high turn over number (Harter and Mann, 2017) therefore, company needs to make an efforts to increase their employee engagement. According to the research conduct by Alias et al,. (2014) organization's talent management also contribute to employee engagement, it means that the higher level of talent management the higher level of employee engagement of the company. Company need to have the ability to identify/hire top individual talent, conducting assessments to place qualified or competent people in important positions, and providing training program to increase their career development because it's the critical component in talent management and most effective engagement tool, when company providing career development employees will feel they have opportunity to get promoted. Therefore, the company must know whether talent management in their organization going well or not. According to Mattone and Vaidya, (2016) there are four factors to analyze the talent management:

1) Deployment : selecting and promoting talent.

2) Diagnostic : continuously assessing leader, individual contributor, and team capability.

3) Development : continuously developing leader, individual contributor, and team capability.

4) Demarcation : differentiating and rewarding performance.
Based on the background that has been described by the author above as well as the data, the author is interested in investigating more deeply about the health of talent management at PT. XYZ Regional West Java, by submitting research entitled "The Health of Talent Management Practice's Factor Analysis of PT XYZ Regional West Java", with the problems that can be formulated as follows:

a) Can the four factor form The Talent Management Practice at PT XYZ Regional West Java?

b) How the talent management at PT XYZ Regional West Java according to the four factor?

\section{Literature Review \\ Talent Management}

According to Sule \& Wahyuningtyas, (2016) Talent management is a integrated activities in managing employees who have high performance at all levels of the organization with the main components of attracting talent through performance management, learning, reviewing talents and maintaining talent through career planning, succession, and the process of binding talents.

Every organization need outstanding highpotential identification and development program. For organization ability to compete with each other they need to increase their talent management systems, based on the previous research, four attributes are considered for the health of talent management, namely:

\section{a. Deployment}

According to Mattone and Vaidya (2016:13) Deployment is about sourcing, screening, and selecting the best of the best leaders and future leaders but also making sure there are structured "bubble-up" meetings to integrate performance and potential assessments, calibrate capability, determine development options, and identify potential replacement scenarios. It means that the company needs to make sure the employee they recruit or promoted have the ability and leadership that the company needs through assessment. 
b. Diagnosis

According to Mattone and Vaidya (2016:13) Diagnosis is obsessively and objectively assessing the requisite skills and capabilities of leaders and potential leaders. It means that the company can diagnosis their employee skill and capabilities for their future leader and the company can diagnosis what employee needs to develop their talent through their continuously assessment.

\section{c. Development}

According to Mattone and Vaidya (2016:13) talent development is coaching, on-the-job development, and training programs-all in support of the competencies and behaviors required to support the new, desired culture. it means that the company can provide coaching, on the job development and training program to fulfil their competencies of success based on their diagnosis assessment.

\section{d. Demarcation}

According to Mattone and Vaidya (2016:13) Demarcation is accurately separating the $A, B$, and $C$ players (performance management) on those competencies and behaviors that support the new, desired vibrant culture. It means that the company can separate their employee by their performance so they can provide compensation and reward for the achievement that has been achieved based on their own performance.

\section{Framework}

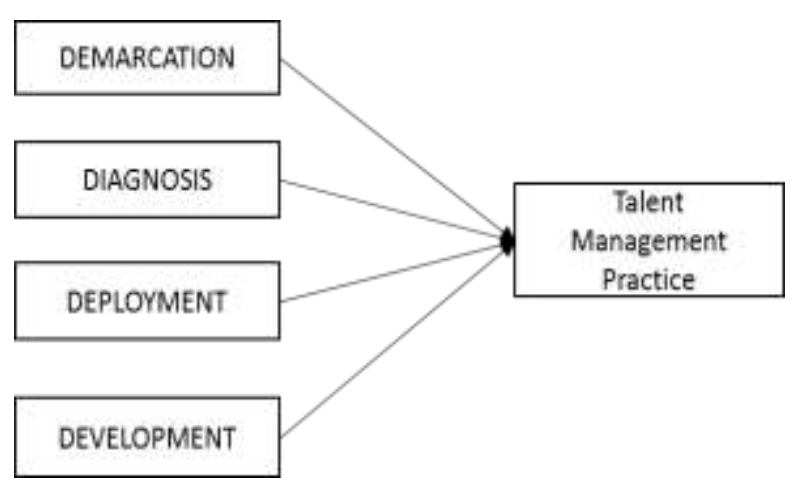

Figure 1 Research Framework

Source: Mattone and Vaidya, (2016)

\section{Research Methods}

Researcher used confirmatory factor analysis with the first-order and second-order confirmatory factor analysis. First, researcher used first-order confirmatory factor analysis to test whether a construct has unidimensional or whether the indicators can confirm a construct or variable. Second, researcher used secondorder confirmatory factor analysis to analyze the structure of the relationship (correlation) between a large number of variables. With second-order confirmatory factor analysis, the researcher can identify the dimensions of a structure and estimated value that can describe how much factor load contained in the latent variables and path diagrams that describe the overall relationship between latent variables and measured variables or measured variable indicators (statements in the questionnaire). In testing if the data was fit, researchers needs to look at the data fit indexes and if the fitness index failed to achieve, it must be reprocessed by releasing certain data one by one until its achieve the fitness index.

\section{Research Result First Order Confirmatory Analysis}

To prove the indicator, researcher connecting the measure variable or in this research is the statement score with the latent variable or the four factor and see is the fitness. The results of the first order confirmatory factor analysis in this study can be seen in table 1:

Table 1

Output First Order Confirmatory Factor Analysis

\begin{tabular}{|c|c|c|}
\hline \multirow[b]{2}{*}{$\begin{array}{l}\text { Latent } \\
\text { Variable }\end{array}$} & \multirow[b]{2}{*}{$\begin{array}{l}\text { Measurable } \\
\text { Variable }\end{array}$} & Output \\
\hline & & $\begin{array}{l}\text { Mediocre } \\
\text { Fit } \\
\text { Category }\end{array}$ \\
\hline Deployment & $\begin{array}{lr}\text { DEP1, } & \text { DEP2, } \\
\text { DEP3, } & \text { DEP4, } \\
\text { DEP5, } & \text { DEP6, } \\
\text { DEP7, } & \text { DEP8, } \\
\text { DEP9, DEP10, } & \text { DEP11, DEP12 }\end{array}$ & $\begin{array}{l}\text { DEP2, } \\
\text { DEP4, } \\
\text { DEP8, } \\
\text { DEP9, } \\
\text { DEP10, } \\
\text { DEP11, } \\
\text { DEP12 }\end{array}$ \\
\hline Diagnosis & $\begin{array}{l}\text { DIA1, DIA2, DIA3, } \\
\text { DIA4, DIA5, DIA6, } \\
\text { DIA7, DIA8, DIA9, } \\
\text { DIA10 }\end{array}$ & $\begin{array}{l}\text { DIA1, } \\
\text { DIA5, } \\
\text { DIA7, } \\
\text { DIA8, }\end{array}$ \\
\hline
\end{tabular}




\begin{tabular}{|c|c|c|c|}
\hline \multirow[t]{2}{*}{$\begin{array}{l}\text { Latent } \\
\text { Variable }\end{array}$} & \multicolumn{2}{|c|}{$\begin{array}{l}\text { Measurable } \\
\text { Variable }\end{array}$} & $\begin{array}{l}\text { Output } \\
\text { Mediocre } \\
\text { Fit }\end{array}$ \\
\hline & & & $\begin{array}{l}\text { DIA9, } \\
\text { DIA10 }\end{array}$ \\
\hline Development & $\begin{array}{l}\text { DEV1, } \\
\text { DEV3, } \\
\text { DEV5, } \\
\text { DEV7, } \\
\text { DEV9 }\end{array}$ & $\begin{array}{l}\text { DEV2, } \\
\text { DEV4, } \\
\text { DEV6, } \\
\text { DEV8, }\end{array}$ & $\begin{array}{l}\text { DEV2, } \\
\text { DEV3, } \\
\text { DEV4, } \\
\text { DEV5, } \\
\text { DEV6, } \\
\text { DEV7, } \\
\text { DEV8, } \\
\text { DEV9 }\end{array}$ \\
\hline Demarcation & $\begin{array}{l}\text { DEM1, } \\
\text { DEM3, } \\
\text { DEM5, } \\
\text { DEM7 }\end{array}$ & $\begin{array}{l}\text { DEM2, } \\
\text { DEM4, } \\
\text { DEM6, }\end{array}$ & $\begin{array}{l}\text { DEM1, } \\
\text { DEM4, } \\
\text { DEM5, } \\
\text { DEM6, } \\
\text { DEM7 }\end{array}$ \\
\hline
\end{tabular}

\section{Second Order Confirmatory Analysis}

To prove the variable, researcher connecting the measure variable or in this research is the statement score with the latent variable or the four factor and then connecting again with one factor as a variable in this research is talent management. The results of the second order confirmatory factor analysis in this study can be seen in table 2 and figure 2 :

\section{Table 2}

\section{Output Second Order Confirmatory Factor} Analysis

\begin{tabular}{|c|c|c|}
\hline \multirow[b]{2}{*}{$\begin{array}{l}\text { Latent } \\
\text { Variable }\end{array}$} & \multirow[b]{2}{*}{$\begin{array}{l}\text { Measurable } \\
\text { Variable }\end{array}$} & Output \\
\hline & & $\begin{array}{l}\text { Mediocre Fit } \\
\text { Category }\end{array}$ \\
\hline Deployment & $\begin{array}{lr}\text { DEP2, } & \text { DEP4, } \\
\text { DEP8, } & \text { DEP9, } \\
\text { DEP10, } & \text { DEP11, } \\
\text { DEP12 } & \\
\end{array}$ & $\begin{array}{l}\text { DEP2, DEP8, } \\
\text { DEP9, } \\
\text { DEP11 }\end{array}$ \\
\hline Diagnosis & $\begin{array}{l}\text { DIA1, } \quad \text { DIA5, } \\
\text { DIA7, } \\
\text { DIA9, DIA10 }\end{array}$ & DIA5, DIA10 \\
\hline Development & $\begin{array}{ll}\text { DEV2, } & \text { DEV3, } \\
\text { DEV4, } & \text { DEV5, } \\
\text { DEV6, } & \text { DEV7, } \\
\text { DEV8, DEV9 }\end{array}$ & $\begin{array}{l}\text { DEV4, DEV5, } \\
\text { DEV7, DEV8, } \\
\text { DEV9 }\end{array}$ \\
\hline Demarcation & $\begin{array}{ll}\text { DEM1, } & \text { DEM4, } \\
\text { DEM5, } & \text { DEM6, } \\
\text { DEM7 } & \end{array}$ & $\begin{array}{l}\text { DEM4, } \\
\text { DEM5, } \\
\text { DEM7 }\end{array}$ \\
\hline
\end{tabular}

The second order confirmatory factor used to identify the estimated value that can describe how much factor loading contained in the latent variable, in this research there are four latent variable namely, Development that has the highest factor loading with the value of 0.58 or $58 \%$ amount of influence which means that Development has the major influence to the health of talent management; then Demarcation also has major influence to the health of talent management as indicated by factor loading with the value of 0.56 or $56 \%$ amount of influence; Diagnosis also contributed to the health of talent management as indicated by factor loading with the value of 0.41 or $41 \%$ amount of influence, , and Deployment that contributes to the health of talent management as indicated by factor loading with the value of 0.31 or $31 \%$ amount of influence. These values can be seen in the path diagram Estimated Value Second-Order Confirmatory Factor Analysis as follows:

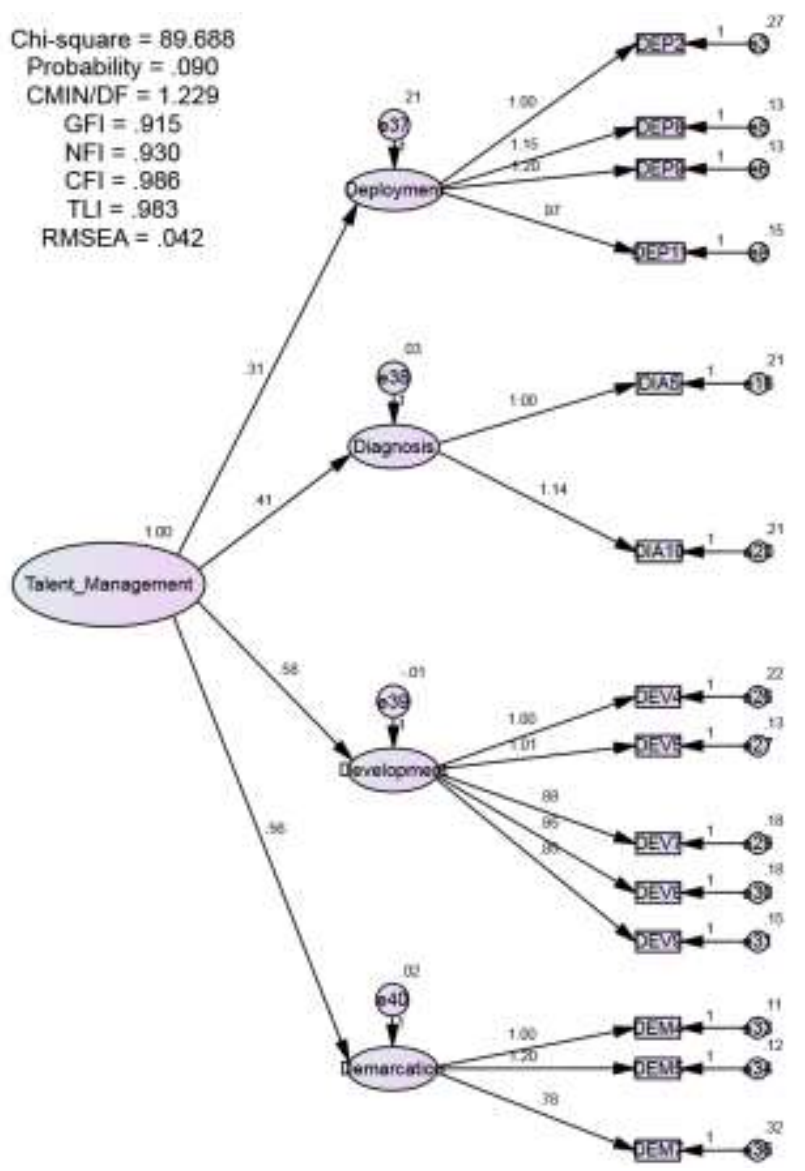

Figure 2

Second Order Analysis Model

Source: Processed by the author 
Descriptive Analysis

\section{Descriptive Analysis of Deployment}

Descriptive Analysis

1) Descriptive Analysis of Deployment

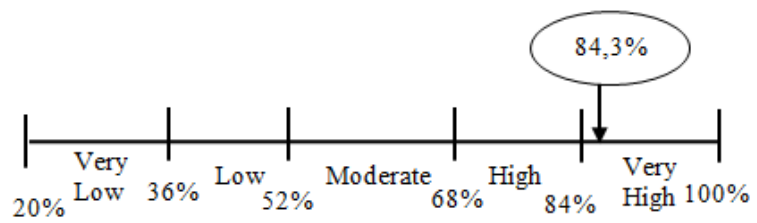

Figure 3

Position of Descriptive Variable in

Source: Processed by the author

Based on the figure above Descriptive factor is in "Very High" category with percentage value $84 \%$ on continuum line. Therefore, we can assume that respondent perception about talent management in Descriptive factor is Very good.

\section{Diagnosis Analysis of Diagnosis}

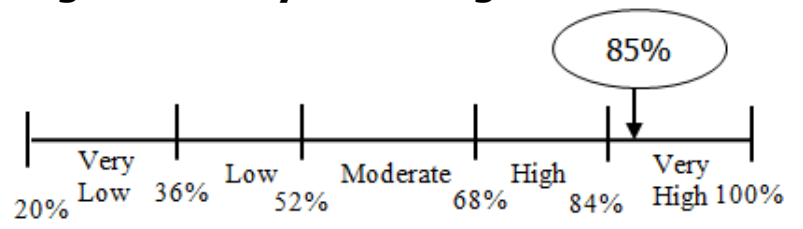

Figure 4

Position of Diagnosis Variable in Continuum

Source: Processed by the author

Based on the figure above Diagnosis is in "Very High" category with percentage value $85 \%$ on continuum line. Therefore, we can assume that respondent perception about talent management in Diagnosis factor is Very good.

\section{Descriptive Analysis of Development}

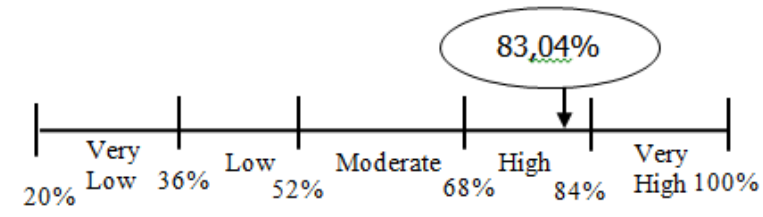

Figure 5

Position of Development Variable in Continuum Line

Source: Processed by the author

Based on the figure above Development is in "High" category with percentage value $83,04 \%$ on continuum line. Therefore, we can assume that respondent perception about talent management in Development factor is good.

\section{Descriptive Analysis of Demarcation}

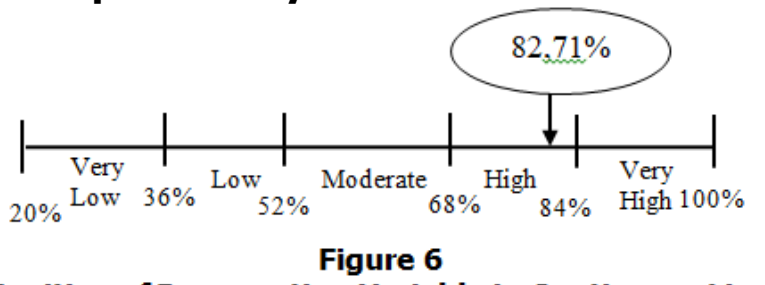

Position of Demarcation Variable in Continuum Line

Source: Processed by the author

Based on the figure above Demarcation is in "High" category with percentage value $83,04 \%$ on continuum line. Therefore, we can assume that respondent perception about talent management in Demarcation factor is good.

\section{Conclusion}

Based on the research conducted on employees of PT XYZ Regional West Java regarding the analysis health of talent management development can be drawn in the following conclusions:

a) Based from the result of first order confirmatory factor analysis each statement can confirm a construct or variable and the result of second order confirmatory factor analysis can identify the dimensions of a structure and estimated value that can describe how much factor load contained in the latent variables, as a result 'it can be concluded that the four factor namely Deployment, Diagnosis, Development, and Demarcation are the factors that contribute to Talent Management and each factor has its amount of influence, namely Deployment with factor loading of 0.31 or $31 \%$ amount of influence, Diagnosis with factor loading of 0.41 or $41 \%$ amount of influence, Development with factor loading of 0,58 or $58 \%$ amount of influence, and Demarcation with factor loading of 0,56 or $56 \%$ amount of influence.

b) Based on the descriptive analysis it can show how the talent management according to the four factor. The talent management in PT XYZ very well managed it's proven by there isn't factor below high category namely 
Deployment has an average value of $84.3 \%$ which include in the very high category with the highest item value DEP2 with an average value $84,46 \%$ the statement of DEP2 is "Our selection/promoting assessment measure leadership capability" based on the result, the assessment used to see skills and competencies that determine whether the candidate can execute the requirements of the position. Diagnosis has an average score of $85 \%$ which include in the very high category with the highest item value DIA5 with an average value $86,62 \%$ the statement of DIA5 is "Our leaders and individual contributors are highly engaged" based on the result, there's $86,62 \%$ employee that feel engage with PT XYZ. The other two factor include in high category namely, Development has an average score of $83.042 \%$ which include in the high category, while Demarcation has an average value $82.71 \%$ which include in the high category.

\section{Suggestion}

Based on the research results, analysis, and conclusions in this study, the following are some suggestions that researchers convey to PT XYZ Regional West Java.

a) Based on the above conclusions, suggestions that given for PT XYZ Regional West Java there focus more on implementing talent management with these four factors namely Deployment, Diagnosis, Development, and Demarcation.

b) Company needs to improved their talent management based on the highest loading factor and see which statement has the lowest percentage value, in this research the result shows that the determinants of talent management, namely Development at PT XYZ Regional West Java, has the highest category with the factor loading of 0.58 while in the descriptive analysis of Development the statement DEV7 and DEV8 has the lowest percentage of score with an average value of $81.69 \%$ and $81,84 \%$. The statement of DEV7 is "our leaders and individual contributor's create individual development plan (IDP) based on the more effective because the supervisor know what their employee career goals and what training their needs to achieve their career goals. The statement of DEV8 "learners are able to track their development progress/certify their knowledge and skills as they progress through development program" researchers suggest that companies need to be more transparency about the result of their employee development program and how much it affect their assessment result.

\section{References}

Alias, N. E., Noor, N. M., \& Hasan, R. (2014). Examining the mediating effect of employee engagement on the relationship between talent management practices and employee retention in the information and technology (IT) organizations in Malaysia, Journal of Human Resources Management and Labor Studies, 2 (22), 227-242.

Dandona, A. (2016). Employee Engagement: A Key To Maximise Organisational Performance. International Journal of Multidisciplinary Educational Research, 5 (3), 266-280.

Gallup. (2017). State of Global Workplace . New York : Gallup Press .

Harter, J., \& Mann, A. (2017). "The Right Culture: Not Just About Employee Satisfaction". Retrieved from https://www.gallup.com/workplace/236 366/right-culture-not-employeesatisfaction.aspx. (Access: 24 November 2020)

Mattone , J., \& Vaidya, N. (2016). Cultural Transformations. New Jersey: John Wiley \& Sons, Inc.

Sule, E. T., \& Wahyuningtyas, R. (2016). Manajemen Talenta Terintegrasi . Yogyakarta: ANDI. 
Jurnal Ekonomi : Journal of Economic

p-ISSN: 2087-8133 | e-ISSN: 2528-326X 